\title{
Identity Crisis: The Agency of Instagram in Schools of Architecture
}

\author{
BENJAMIN J. SMITH \\ Tulane University
}

\begin{abstract}
Thefocusofthis paper addresses themes of neoliberalism, university commercialization and marketing, architecture school identity formation as a representational practice through social media, andtheroleofimagecurationanditsproductionincontemporary architecture. This paper emerged after hearing the phrase'buyer's motive,' which explained whatschools needed to consider for attracting students to their programs at a conference by Ruffalo Noel Levtiz on recruitment, marketing, and retention in higher education in the United States. The use of theword, 'buyer', instead of 'student', or 'prospective student', or 'learner' seemingly transformed the production of engaged education to its passive consumption.
\end{abstract}

At universities, a faculty member's work, whether directly, or indirectly, does relate to aspects of recruitment, marketing, and retention, whether by attending recruitment fairs and participating in admissions and open houses, or compelling students to apply and stay through course content and research. Evaluating the presence of Instagram offers one strategy to consider the ways in which schools use social media platforms to increase their reach and convey mission through tangible content. This content includes student work, faculty work and scholarship, lectures series, events, and school and course accomplishments. The curation of these diverse examples articulates a school's mission, it lets people know what the school cares about, and how the school asserts its relevance. A question emerges whether a marketing tool, such as Instagram, capitulates to mechanisms of neoliberalism, furthering the commercialization of higher education by influencing the decisions of prospective and current students to 'buy' its product? Universities are not like cars or smartphones, or other commodified products, however, they do convey desirable traits, such as prestige, career prospects, stimulating environments for learning and creative thinking, and engagement with meaningful activities. Considering higher education as a 'product' presents challenges, yet, with the rising cost of education, the increased burden of student debt, and the competition between schools for students, schools should be aware of the diverse factors weighing on students' academic choices and how marketing affects those choices.

Tempering the cynical view of education's commercialization one might observe how using Instagram broadcasts what a school of architecture does and how that contributes to scholarship and the discipline by showcasing faculty publications and scholarship, buildings and projects, awards and accolades, and design techniques and technologies, etc. Coupling the rich visual nature of architecture with the contemporary culture of rapid image consumption via mobile devices, an application like Instagram gives architecture relevance to communicate advancement in critical themes for social, technological, and aesthetic progress.

In Peter Cook's introduction to his book, Drawing: The Motive Force of Architecture, he raised the point, when questioning a drawing's motive, that, "from whatever starting point, it seems that clarity of priorities is at the centre of the issue." ${ }^{1}$ For Cook, strategies of communication, become an integral attribute of a drawing, and by extension, in this case, the image. In the case of an Instagram image, whether an example of an architectural work or a photograph of an event, the artifactual nature of the representation, the representation of a representation, as well as the representation of image conveys motive by being selected, captioned, and hashtagged as a precise selection to communicate content. Through the image, to be discussed, liked, shared, and critiqued, it conveys an intention to spark intrigue with purpose. The duality of Instagram becomes a strategic process to generate interest and attract students to schools and their programs, and to convey what architecture does and why it matters. This dialectic of capitalist ambition and disciplinary progress does not reconcile easily. Differences in the perception of communication methods, and the underlying motives from schools and the community of people schools involve, occur.

Aspects of higher education have changed relative to neoliberal influences. Neoliberalism emerged as a dominant ideological pursuit in the 20th century, and shaped political and social structures through laissez-faire attitudes toward economics that moved away from Keynesian economic strategies. David Harvey wrote in his 2005 book, A Brief History of Neoliberalism, that "the founding figures of neoliberal thought took political ideals of human dignity and individual freedom as fundamental, as 'central to civilization'."' However, how neoliberalism progressed, according to Harvey, deviated from those optimistic goals and transformed. Havey states about the progression of neoliberalism that "social good will be maximized by maximizing the reach and frequency of market transactions, and it seeks to bring all human action into the domain of the market, ${ }^{\prime 3}$ creating a culture of 'deregulation' and 'privatization' where capital guides decision-making.

In Michel Foucault's lectures at the Collège de France from 1978 and 1979 he differentiated European and American neoliberalism. Foucault asserted, "the demand for liberalism founds the state [in the former] rather than the state limiting itself through liberalism [in the latter]." ${ }^{4}$ According to Foucault, American 
neoliberalism presented people as capital producing machines, inseparable from their ability to do work, giving "a strictly economic interpretation of a whole domain previously thought to be non-economic Capital is thus defined as that which makes future income possible This is not a conception of a labor power; it is a conception of a capital-ability so that the worker appears as a sort of enterprise for himself." ${ }^{\prime 5}$ The solipsistic effect of being an 'enterprise for yourself' feels at home with social media habits of ego manufacturing identity curation. Extending the 'capital-ability' to a school, Instagram can be understood as a neoliberal tool for capital that makes future income possible through its potential to attract students to purchase the product of education.

Two texts that grapple with market driven principles in higher education include Eric Anctil's 2008 ASHE Higher Education Report, Selling Higher Education: Marketing and Advertising America's Colleges and Universities and Henry Giroux's book, Neoliberalism's War on Higher Education. Anctil presented the view that schools should not separate market-driven from mission-driven enterprises. The executive summary at the beginning of the book claimed that today's universities maintain 'viability' by understanding that "the market supports and propels the mission [of a university] rather than obstructs it." ${ }^{1}$ Anctil identified higher education as a responsive 'social institution' to market influences, recognizing a paradox of university marketing. Anctil stated, "students are the product of education and they are its customers Not only does a school have to get your attention and attract you to apply, it has to then determine your worthiness and support you through your time on campus so you can positively contribute to the environment that attracted you to the institution in the first place."7 Anctil's understanding of the lifecycle of a student shared similarities with three qualities in Henri Lefebvre's conceptualization of space in his book, The Production of Space. Students are attracted to a university by a 'representational space' of the schools image and identity, they construct 'spatial practice' through their actions within a university environment, and they become 'representations of space' that create representational content. ${ }^{8}$

Alternative to Anctil, Giroux took an oppositional view toward higher education's relationship to market influences. Giroux views neoliberalism as an assault to higher education that erodes an institution's ability to promote democratic ideals that challenge status quo political paradigms due to the effects of a survival of the fittest mentality encouraged by free market capitalism. In his book he made this point clear, presenting themes which he attributed to David Harvey. "[Neoliberal policy] privileges personal responsibility over larger social forces, reinforces the gap between the rich and the poor by redistributing wealth to the most powerful and wealthy individuals and groups, and it fosters a mode of public pedagogy that privileges the entrepreneurial subject while encouraging a value system that promotes self-interest, if not unchecked selfishness." Institutions of higher education, whose missions align with research for social and cultural good and public service through education, face challenges within neoliberal contexts that contradict many of its values. Giroux recognized higher education as a place to engage critical thinking, to imagine freely, to take risks - all qualities he finds slipping away from universities through neoliberal motives guiding students as consumers of a product to sustain economic conditions. Giroux also directed criticism toward the contemporary fascination with celebrity. "Celebrity has become the principal expression of value in a society in which only commodified objects have any value.." ${ }^{10}$ Giroux's charged claim regarding celebrity offered a unique perspective on celebrity culture, giving the expression 'Instagram famous' new meaning. In a discipline that uses terms like 'starchitect' and 'starchitecture,' architecture schools can also rise to celebrity status through the cult of the image as cultural influencers at a broad scale.

Architecture schools are competitive environments for faculty, students, and administrations. In many ways, competition promotes healthy progress to advance the field through the production of new knowledge, through design and scholarship, through critique and new working methods, as long as it does not undermine collaboration and the diversity of a community culture. While architecture remains a field largely determined by market forces and economic influences, the ways in which academics and universities teach students and conduct scholarship should be sensitive to the various scales that it responds to social, economic, and political pressures. As a discipline, we engage diverse topics and make positive impacts toward change, even in the simple awareness of the effects of image culture and cultivating identity. The goal of this research has been to assess social media marketing practices affecting schools of architecture by articulating their relationship to latent factors of neoliberalism. In a contemporary context where architecture schools not only compete for enrollment but also for disciplinary attention, social media offers a lens onto which the crossroads of academia's mission converges in a synthesis of new knowledge and selling its image to students.

\section{ENDNOTES}

1. Cook, Peter. Drawing: The Motive Force of Architecture. England: Wiley, 2008, 22

2. Harvey, David. A Brief History of Neoliberalism (2005). Oxford: Oxford University Press, 2007, 5.

3. Ibid., 3.

4. Foucault, Michel. The Birth of Biopolitics: Lectures at the Collège de France 1978-1979. New York: Picador, 2008, 217

5. Ibid., 219-225.

6. Anctil, Eric J. Selling Higher Education: Marketing and Advertising America's Colleges and Universities. Hoboken: Wiley Periodicals, Inc., 2008, viii.

7. Ibid., 3-13.

8. Lefbvre, Henri. The Production of Space. Oxford: Blackwell Publishers, 2000.

9. Giroux, Henry. Neoliberalism's War on Higher Education. Chicago: Haymarket Books, 2014, 1.

10. Ibid., 49 